\title{
VARIASI JUMLAH LUBANG VENTILASI DISC BRAKE SERTA PENGARUHNYA TERHADAP JARAK PENGEREMAN DAN TEMPERATUR PERMUKAAN DISC
}

\author{
Muhammad Hasan Albana*, Yulmedia Putra* \\ * Politeknik Negeri Batam \\ Mechanical Engineering study Program \\ Jln. Ahmad Yani, Batam Centre, Batam 29461, Indonesia \\ E-mail: hasan@polibatam.ac.id
}

\begin{abstract}
Abstrak
Disc brake adalah salah satu jenis rem yang banyak diaplikasikan pada kendaraan seperti mobil dan sepeda motor. Pada disc brake biasanya dibuat lubang pada bagian permukaannya dengan tujuan supaya proses perpindahan panas pada disc brake tersebut cepat terjadi. Penelitian ini bertujuan untuk melihat pengaruh jumlah lubang ventilasi pada disc brake terhadap jarak pengereman dan temperatur permukaan disc. Jumlah lubang ventilasi pada disc brake yang divariasikan pada penelitian ini adalah 36, 40, 48 dan 60. Pengujian dilakukan secara eksperimen dengan menguji langsung disc brake pada kendaraan dan dilakukan uji jalan. Hasil penelitian menunjukkan bahwa tempe- ratur pada permukaan disc brake dengan jumlah lubang ventilasi 36, setelah proses pengereman, lebih tinggi dibandingkan disc brake dengan jumlah lubang ventilasi 40, 48 dan 60. Akan tetapi jarak pengereman yang dibutuh- kan oleh disc brake dengan jumlah lubang ventilasi 36 tersebut lebih pendek dibandingkan disc brake lain dengan jumlah lubang ventilasi yang lebih banyak. Semakin banyak jumlah lubang ventilasi pada disc brake maka tempera- tur yang dihasilkan pada permukaan disc brake setelah pengereman akan semakin rendah akan tetapi jarak pengere- man yang dibutuhkan semakin jauh atau panjang.
\end{abstract}

Kata kunci: Disc brake, jarak pengereman, lubang ventilasi, temperatur permukaan disc

\begin{abstract}
Disc brake is one type of brake that is widely applied to vehicles such as cars and motorcycles. Disc brakes usually produced by making hollows on it is surface to cooling process. This study to see the effect of the number of ventilation holes in the disc brake on the braking distance and surface temperature of the disc. The number of ventilation holes in the disc brake varied in this study were 36, 40, 48 and 60 . The test was conducted experimentally by directly testing the disc brake on the vehicle and the road test was performed. The results show that the temperature on the disc brake surface with the number of ventilation 36, after braking process, is higher than the disc brake with the number of ventilation holes 40,48 and 60 . However, the braking distance required by the disc brake by the number of holes ventilation 36 is shorter than other disc brakes with more number of ventilation holes.
\end{abstract}

Keywords : Braking distance, disc brake, surface temperature of disc, ventilation hole

\section{Pendahuluan}

Peran rem bagi sebuah kendaraan seperti mobil, sepeda motor, truk, pesawat terbang dan lain sebagainya ada- lah sangat penting. Pada saat sekarang ini bisa dikata- kan tidak ada satu kendaraanpun yang diproduksi tanpa dilengkapi dengan sistem pengereman karena jika sebuah kendaraan tidak dilengkapi dengan sistem pengereman maka tidak akan boleh dipasarkan karena tidak memenuhi standar yang telah ditetapkan oleh pe- merintah.
Fungsi dasar dari rem adalah menyerap energi kinetik dan dibuang dalam bentuk panas [1]. Ugural, Ansel $\mathrm{C}$ [2] mendefinisikan fungsi rem untuk menyerap energi kinetik dari kendaraan yang bergerak sehingga kecepa- tannya bisa dikontrol. Rem mengubah energi mekanik menjadi energi panas. Energi yang diserap dan dibuang tersebut bisa dikatakan cukup besar sehingga desain rem dan pemilihan material yang digunakan untuk sis- tem rem harus dilakukan secara teliti dan seksama. Ada banyak jenis rem yang digunakan sebagaimana terlihat pada Gambar 1 namun jenis rem yang paling banyak digunakan untuk mobil dan sepeda motor adalah rem tromol (drum brake) dan rem cakram (disc brake). 


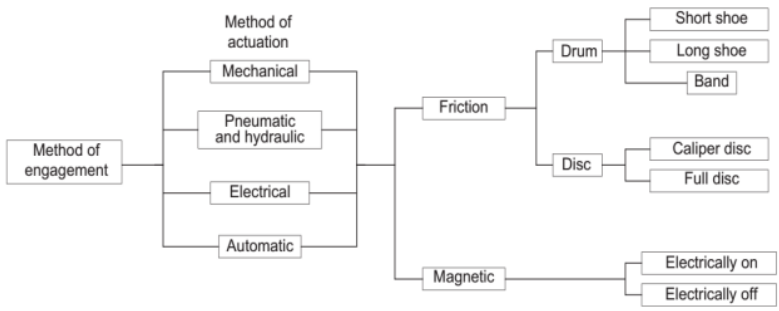

Gambar 1: Klasifikasi Rem [1]

Disc brake sangat umum digunakan pada kendaraan seperti pada mobil dan sepeda motor. Disc brake ini terdiri dari piringan (disc) yang biasanya terbuat dari baja tuang dan dibautkan pada wheel hub. Piringan rem ini disisipkan di antara dua buah pad yang digerakkan oleh piston sebagaimana terlihat pada Gambar 2. Keti- ka pedal rem ditekan, tekanan fluida menyebabkan pad menekan piringan (disc) sehingga terjadi gesekan [2]. Gesekan ini menyebabkan putaran disc melambat se- hingga secara otomatis putaran roda kendaraan juga melambat atau malah berhenti.

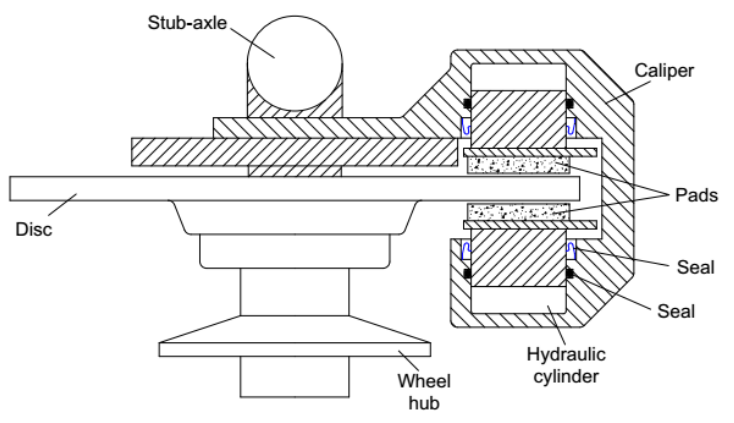

Gambar 2: Automotive disc brake [1]

Pada disc brake biasanya dibuat lubang atau slot pada bagian permukaannya maupun pada bagian sisinya. Bentuk dan konfigurasi dari lubang atau slot ini berma- cam-macam. Tujuan dari dibuatnya lubang dan slot ini adalah sebagai ventilasi supaya proses perpindahan panas cepat terjadi. Selama pengereman, energi kinetik diubah menjadi energi panas dan $90 \%$ energi panas ini diserap oleh piringan (disc) rem [3]. Temperatur yang dihasilkan dalam proses pengereman kendaraan peumpang bisa mencapai 900 Calcius [4]. Pada Disc brake berbentuk solid (tanpa lubang ventilasi), proses penghilangan panas berlangsung lambat sehingga dibuatlah lubang ventilasi untuk meningkatkan proses pendinginan disc brake melalui sirkulasi udara.

Permasalahan yang dihadapi oleh disc brake dengan lubang ventilasi adalah terbentuknya retakan (crack formation) terutama ketika berada di bawah tekanan yang besar dalam proses pengereman [3]. Dalam hal menahan stress, disc brake berbentuk solid lebih memiliki ketahanan dibandingkan disc brake dengan lubang ventilasi. Permasalahan berikutnya adalah sema- kin banyak jumlah lubang ventilasi disc brake maka semakin jauh jarak pengereman. Siahaan dan Herma- wan [5] melakukan pengujian pada 3 buah disc brake dengan jumlah lubang ventilasi 24, 32 dan 42 dengan metode pengujian stationary. Hasil penelitian mereka memperlihatkan bahwa disc brake dengan jumlah lubang ventilasi 24 menghasilkan jarak pengereman yang lebih pendek dibandingkan disc brake dengan jumlah lubang ventilasi 32 dan 42 .

Pada penelitian ini, 4 jenis disc brake dengan jumlah lubang ventilasi 36, 40, 48 dan 60 diuji secara langsung pada kendaraan. Disc brake dengan jumlah lubang ventilassi 36 adalah disc brake standar dari pabrikan sepeda motor. Metode pengujian bukan stationary tetapi uji jalan dan jenis disc brake yang digunakan adalah untuk sepeda motor. Data yang diambil adalah jarak pengereman dan temperatur yang dihasilkan pada permukaan disc brake setelah proses pengereman.

\section{Metode Penelitian}

Penelitian ini dilakukan secara eksperimen dengan metode uji jalan secara langsung pada kendaraan (sepeda motor). Jumlah sepeda motor yang digunakan untuk pengujian adalah 1 sehingga disc brake dengan jumlah lubang yang berbeda-beda tersebut dipasang secara bergantian. Hal ini bertujuan supaya karakteris- tik pengereman sama sehingga hasil pengujian lebih akurat. Bentuk dari disc brake dengan jumlah lubang ventilasi 36, 40, 48 dan 60 diperlihatkan pada Gambar 3 sampai Gambar 6.

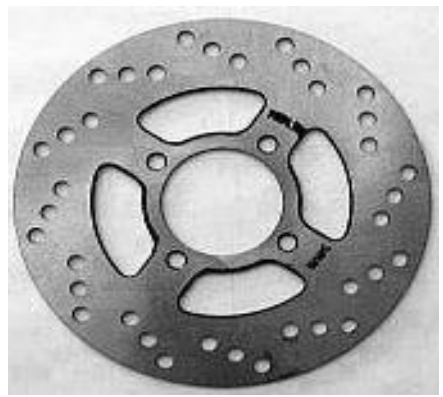

Gambar 3: Disc brake dengan 36 lubang ventilasi

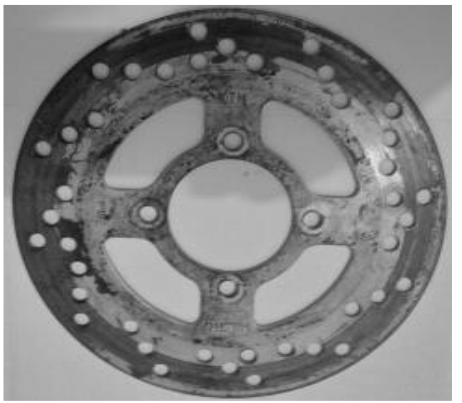

Gambar 4: Disc brake dengan 40 lubang ventilasi 


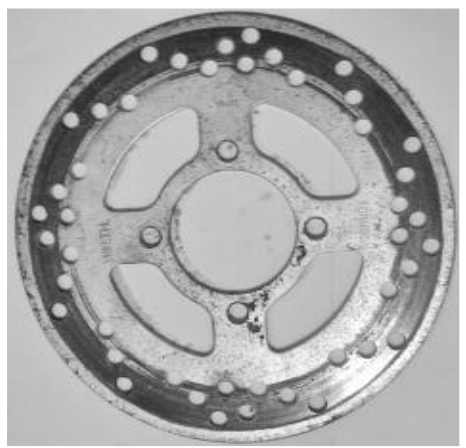

Gambar 5: Disc brake dengan 48 lubang ventilasi

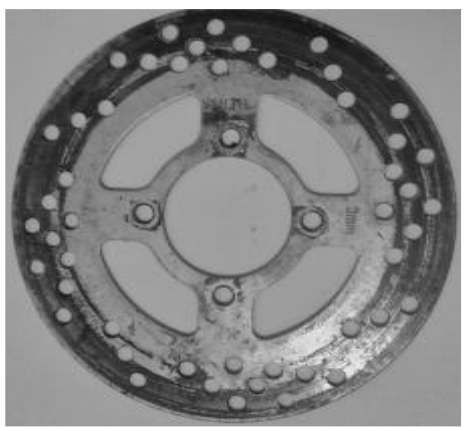

Gambar 6: Disc brake dengan 60 lubang ventilasi

Jumlah pengendara yang mengendarai sepeda motor uji adalah satu orang yang sama untuk semua jenis variabel uji dengan tujuan beban yang diterima oleh sepeda motor sama serta karakteristik pengereman juga sama sehingga hasil pengujian diharapkan bisa lebih valid. Kecepatan sepeda motor untuk semua jenis disc brake yang diuji adalah $30 \mathrm{~km} / \mathrm{jam}$. Setelah melakukan satu kali pengujian disc brake didinginkan terlebih dahulu sampai temperatus disc brake sama dengan temperatur lingkungan. Dalam melakukan pengujian, setiap disc brake yang diuji menempuh jarak yang sama sebelum proses pengereman dilakukan. Setelah dilakukan pengereman dan sepeda motor berhenti, segera dilakukan pengukuran temperatur disc brake dan pengukuran jarak pengereman. Jarak pengereman adalah jarak dari pengereman kendaraan dilakukan sampai kendaraan berhenti total. Untuk setiap jenis disc brake dilakukan pengujian sebanyak 3 kali.

\section{Hasil dan Pembahasan}

Dari pengujian yang dilakukan terhadap 4 jenis disc brake dengan jumlah lubang ventilasi yang berbedabeda yaitu 36, 40,48 dan 60 diketahui bahwa lubang ventilasi pada disc brake sangat berpengaruh terhadap proses pendinginan disc brake itu sendiri. Sebagaima- na terlihat pada Gambar 7, disc brake dengan jumlah lubang ventilasi 36 buah, setelah proses pengereman, menghasilkan temperatur rata-rata $73^{\circ}$ Calcius sedang- kan disc brake dengan jumlah lubang ventilasi 40, 48 dan 60 setelah proses pengereman menghasilkan tem- peratur rata-rata 55 ,
53 dan $51^{\circ}$ Calcius. Disc brake de- ngan jumlah lubang yang lebih sedikit, setelah proses pengereman menghasilkan temperatur permukaan yang lebih tinggi. Semakin banyak jumlah lubang ven- tilasi pada permukaan disc brake tersebut maka temperatur permukaan setelah proses pengereman menjadi lebih rendah. Dengan ini terlihat jelas fungsi dari lu- bang-lubang ventilasi pada permukaan disc brake da- lam proses perpindahan panas setelah pengereman di- lakukan.

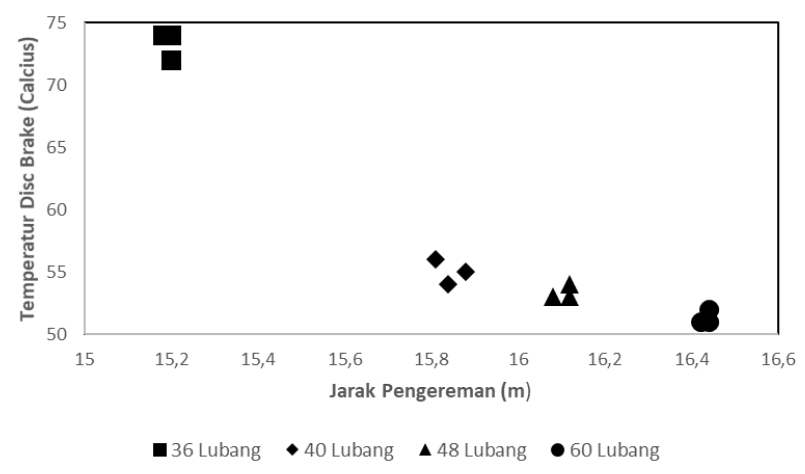

Gambar 7: Temperatur disc brake vs jarak pengereman

Gambar 7 juga memperlihatkan jarak pengereman yang dibutuhkan ketika menggunakan disc brake. Semakin banyak jumlah lubang ventilasi pada permukaan disc brake maka jarak pengereman yang dibutuhkan semakin panjang. Untuk disc brake dengan jumlah lu- bang ventilasi 36, jarak pengereman yang dibutuhkan adalah 15,2 m. Untuk disc brake dengan jumlah lubang ventilasi 40 buah jarak pengereman yang dibutuhkan adalah 15,8 m. Untuk disc brake dengan jumlah lubang ventilasi 48 buah jarak pengereman yang dibutuhkan adalah 16,1 $\mathrm{m}$ dan untuk disc brake dengan jumlah lubang ventilasi 60 buah jarak pengereman yang dibutuhkan adalah $16,4 \mathrm{~m}$.

Apabila jarak pengereman dan temperatur pada permu- kaan disc brake dibandingkan maka antara kedua variabel tesebut berbanding terbalik. Sebagai contoh disc brake dengan jumlah lubang ventilasi 36 buah. Setelah dilakukan pengeraman, temperatur yang diha- silkan pada permukaan disc brake tersebut lebih tinggi dibandingkan temperatur yang dihasilkan oleh disc brake lain dengan jumlah lubang ventilasi yang lebih banyak. Akan tetapi disc brake dengan jumlah lubang ventilasi 36 tersebut memiliki kelebihan yaitu jarak pengereman yang lebih pendek dibandingkan disc brake lain dengan jumlah lubang ventilasi yang lebih banyak. Demikian juga disc brake dengan jumlah lubang ventilasi 60 buah, setelah dilakukan pengere- man, temperatur yang dihasilkan pada permukaan disc brake paling rendah dibandingkan disc brake lain de- ngan jumlah lubang ventilasi yang lebih sedikit akan tetapi jarak pengereman yang dibutuhkan lebih jauh. 


\section{Kesimpulan}

Disc brake dengan jumlah lubang ventilasi yang lebih sedikit, setelah proses pengereman, akan menghasilkan temperatur yang lebih tinggi pada permukaan disc dibandingkan disc brake lain dengan jumlah lubang ventilasi yang lebih banyak akan tetapi jarak pengera- man yang dibutuhkan oleh disc brake ini lebih pendek dibandingkan dengan disc brake lain dengan jumlah lubang ventilasi yang lebih banyak. Demikian juga sebaliknya, disc brake dengan jumlah lubang ventilasi yang lebih banyak, setelah pengereman, temperatur yang dihasilkan pada permukan disc akan lebih rendah dibandingkan disc brake lain dengan jumlah lubang ventilasi yang lebih sedikit akan tetapi jarak pengere- man yang dibutuhkan menjadi lebih panjang.

\section{Daftar Rujukan}

[1] Childs, Peter R.N, Mechanical Design Engineering Handbook., Elsevier, 2014.

[2] Ugural, Anser C, Mechanical Design of Machine Component second edition, CRC Press, 2015.

[3] Yildiz, Y dan Duzgun, M, "Stress analysis of ventilated brake discs using the finite element method", International Journal of Automotive Technology, Vol. 11, No. 1, pp. 133-138, 2010.

[4] Mackin, Thomas J, et al, "Thermal cracking in disc brakes", Engineering Failure Ananlysis, Vol. 9, hal. 63-76, 2002.

[5] Siahaan, Ian hardianto dan Hermawan, Ervin Edi, "A number of venting holes disc brake impact on stationary test", Seminar Nasional Teknik Mesin 8, Surabaya, Indonesia, hal. 19-22. 